\title{
Number, Distribution, and Morphology of Retinal Ganglion Cells with Axons Regenerated into Peripheral Nerve Graft in Adult Cats
}

\author{
Masami Watanabe, ${ }^{1}$ Hajime Sawai, ${ }^{2}$ and Yutaka Fukuda ${ }^{2}$ \\ ${ }^{1}$ Department of Physiology, Institute for Developmental Research, Aichi Colony, Kasugai 480-03, and ${ }^{2}$ Department of \\ Physiology, Osaka University Medical School, Suita, Osaka 565, Japan
}

\begin{abstract}
The optic nerve of adult cats was transected and an autologous peripheral nerve was transplanted to the stump. Two months later retinal ganglion cells (RGCs) that had regenerated their axons were retrogradely labeled with fluorescent dye injected into the graft. The more than $\mathbf{4 0 0 0}$ labeled cells, which were $3.0-4.3 \%$ of total ganglion cell number in the intact retina, were distributed in a high-density area elongating horizontally, in a pattern similar to that observed in the intact retina.
\end{abstract}

The dendritic morphology of RGCs with regenerated axons was examined after intracellular injections of HRP or Lucifer yellow in vitro. The morphology of $\alpha$ - and $\gamma$-cells appeared comparable to normal, whereas the dendrites of some $\beta$-cells seemed to degenerate. Some "unclassified" cells could not be identified as $\alpha-, \beta-$, or $\gamma$-cells. The main dendrites of most unclassified cells were thin and less ramified than $\alpha$ - and $\beta$-cells. Some unciassified cells had a vacant area in their dendritic fields, suggesting degenerative change in dendrites. The distal dendrites of some unclassified and $\gamma$-cells had many fine processes that probably regrew during axonal regeneration.

The proportion of $\alpha-, \beta$, and other cells including $\gamma$ - and unclassified cells in the regenerating cell population was evaluated by examining all of the Lucifer yellow-injected cells in local patches. The average proportion of $\alpha$-cells was $23.9 \%$, about six times higher than in intact retinas. The average proportion of $\beta$-cells was $50.3 \%$, slightly higher than in intact retinas. The remaining cells $(25.7 \%)$ could not be categorized as $\alpha$ or $\beta$; this proportion is about half that found in intact retinas. These findings suggest that $\alpha$-cells have the highest capacity to regenerate their axons into nerve grafts, rather than all types equally regenerating their axons.

[Key words: adult cat, axonal regeneration, retinal ganglion cells, dendritic morphology, $\alpha$-cells, $\beta$-cells, unclassified cells, intracellular injection, dendritic growth]

Retinal ganglion cells (RGCs) of rodents have the capacity to regenerate their transected axons into a peripheral nerve graft transplanted to the optic nerve stump (So and Aguayo, 1985;

\footnotetext{
Received July 27, 1992; revised Nov. 6, 1992; accepted Nov. 19, 1992.

This study was supported by Grants-in-Aid for Scientific Research (02220212 $03044097,03670841,03 N P 0101$ ) from the Ministry of Education, Culture and Science of Japan. We thank Dr. M. Rasminsky for his valuable comments on the manuscript, Dr. R. W. Rodieck for providing original data, and Drs. M. Ito and

I. Uramoto for their encouragement and support throughout the study.

Correspondence should be addressed to Masami Watanabe, Ph.D., Department of Physiology, Institute for Developmental Research, Aichi Colony, Kasugai, Aichi 480-03, Japan.

Copyright (C) 1993 Society for Neuroscience $0270-6474 / 93 / 132105-13 \$ 05.00 / 0$
}

Vidal-Sanz et al, 1987; Carter et al., 1989). In our previous study we found that cat RGCs are also capable of axonal regeneration along a peripheral nerve graft (Watanabe et al., 1991a). With intracellular injections of HRP, we demonstrated that the cat RGCs with regenerated axons include $\alpha$-, $\beta$-, and possibly $\gamma$-cells. The dendritic morphology of RGCs with regenerated axons was comparable to the morphology of RGCs of normal cats as seen with the same method of intracellular injection (Rodieck and Watanabe, 1986).

Cats are appropriate for research on optic nerve regeneration since the morphology and physiology of RGCs have been extensively investigated in cats (for review, see Rodieck, 1979). Boycott and Wässle (1974) identified three main RGC groups according to their soma size and dendritic morphology. $\alpha$-Cells, with the largest soma size, are characterized by thick primary dendrites that ramify frequently and extend to cover a wide area. The dendrites of $\beta$-cells ramify frequently and cover a smaller field more densely, whereas those of $\gamma$-cells, with the smallest soma size, are long and thin with the least branching. Physiologically, cat RGCs are classified into three types (Cleland and Levick, 1974; Stone and Fukuda, 1974). Y-cells respond briskly and transiently to photic stimuli; $\mathrm{X}$-cells respond in a sustained and brisk fashion. Conduction velocity and axonal caliber are the largest in $Y$-cells. W-cells comprise several types: on- or off-tonic, on- or off-phasic, and on-off-phasic (Fukuda and Stone, 1974; Stone and Fukuda, 1974). By performing electrophysiologic recording and intracellular dye injections with the same electrode, it has been shown that $\mathrm{Y}$ - and X-cells correspond to $\alpha$ - and $\beta$-cells, respectivcly (Saito, 1983; Fukuda et al., 1984; Stanford and Sherman, 1984).

In our previous study, the proportion of axotomized cat RGCs that regenerated their axons into peripheral nerve grafts was estimated to be less than $1 \%$ of the total (Watanabe et al., 1991a), while as many as $11 \%$ of axotomized rat RGCs were found to regenerate their axons (Vidal-Sanz et al., 1987). Since we observed many apparently normal but unlabeled cells besides labeled cells, it seemed possible that HRP labeling underestimated the number of RGCs with regenerated axons. The first objective of this study was to provide more accurate estimates of the numbers of RGCs with regenerated axons by using a more sensitive tracer for the retrograde labeling. This method made it possible to evaluate more precisely the distribution of RGCs with regenerated axons in the whole-mounted retina. Our second objective was to determine whether there were differences in the capacity of different classes of cat RGCs to regencratc their axons. For this purpose we injected Lucifer yellow (Tauchi and Masland, 1984) into all the retrogradely labeled cells in several patches of retinas, and then estimated the relative pro- 
portions of $\alpha-, \beta-$, and other cells in the regenerating cell population.

A preliminary report of part of the present study appeared previously (Watanabe et al., 1991b).

\section{Materials and Methods}

\section{Transplantation surgery}

Transplantation surgery was done under sterile conditions. Cats 1-3 years old of either sex, weighing $2-4 \mathrm{~kg}$, were sedated with an intramuscular injection of $57 \mathrm{mg}$ ketamine $\mathrm{HCl}$ and then anesthetized with a gas mixture of $1-2 \%$ halothane, nitrous oxide ( 1 liter $/ \mathrm{min}$ ), and oxygen (1 liter/min). The heart rate was stabilized with atropine sulfate $(1 \mathrm{mg} /$ $\mathrm{kg}$ body weight) injected intraperitoneally, and the electrocardiogram was monitored during anesthesia.

The left optic nerve was exposed under a dissecting microscope and transected 4-6 $\mathrm{mm}$ posterior to the eyeball with fine spring scissors for corneal surgery. Care was taken not to injure blood vessels, especially the ophthalmic artery that enters the sclera from the ventral margin of the optic nerve. Integrity of the retinal circulation was verified with an ophthalmoscope after optic nerve transection.

The anterior branch of the left sciatic nerve $(30-45 \mathrm{~mm})$ was excised and the skin was closed after administration of penicillin powder $(4 x$ $\left.10^{5} \mathrm{U}\right)$. The peripheral nerve was sutured to the optic nerve stump with nylon thread (Ethilon 10-0, Ethicon), and the other end of the graft was left in the temporalis muscle. Penicillin powder $\left(4 \times 10^{3} \mathrm{U}\right)$ was administered in the retrobulbar space. After recovery from anesthesia, the cats were able to walk without major deficit.

\section{Retrograde labeling of $R G C s$ with regenerated axons}

Two months after transplantation, the graft was reexposed under gas anesthesia for retrograde labeling of RGCs that regenerated axons into the grafts. Either $10 \mu \mathrm{l}$ of $10 \%$ (w/v in water) tetramethylrhodamineconjugated dextran (TMRD; Molecular Probes; MW $=10,000$ ) or 10 $\mu 1$ of $10 \%$ (w/v in water) fluorescein-conjugated dextran (FLD; Molecular Probes; $M W=10,000$ ) was injected into the graft at least $10 \mathrm{~mm}$ distal to the site of apposition of the graft to the optic nerve stump in each case. The cats were used after $2 \mathrm{~d}$ survival.

\section{Number, soma size, and dendritic field size of the RGCs with regenerated axons}

Numbers of RGCs. RGCs with regenerated axons were counted as cells labeled retrogradely with TMRD. After injections of Lucifer yellow (see below), two retinas $(52 \mathrm{~L}, 55 \mathrm{~L})$ were fixed with $1 \%$ paraformaldehyde in $0.1 \mathrm{M}$ phosphate buffer and mounted in $0.1 \mathrm{M}$ phosphate buffer supplemented with $0.1 \%$ sodium azide. The positions of TMRD-labeled cells were recorded at $10 \mu \mathrm{m}$ resolution using a stage scanner (Micro Scanner, Sapporo Breweries) connected to a personal computer.

Soma sizes of the RGCs. Two months after transplantation, three cats (cats 6,17 , and 19) were anesthetized with the above gas mixture, and the graft was exposed. Ten microliters of $15 \%(\mathrm{w} / \mathrm{v})$ horseradish peroxidase (HRP; Sigma type 6) in saline were injected into the graft with a Hamilton syringe. The injection point was at least $10 \mathrm{~mm}$ distal to the sutured point in each case. Two to three days after HRP labeling, the cats were anesthetized by an overdose of sodium pentobarbital. Approximately one liter of $1 \%$ paraformaldehyde and $1.25 \%$ glutaraldehyde in $0.1 \mathrm{~m}$ phosphate buffer ( $\mathrm{pH} 7.4$ ) was perfused transcardially. The left eye was enucleated, the retina was dissected in $0.1 \mathrm{~m}$ phosphatc buffer, and several incisions were made to flatten the retina. The retinas were reacted with diaminobenzidine $(\mathrm{DAB} ; 0.5 \mathrm{mg} / \mathrm{ml})$ and $\mathrm{H}_{2} \mathrm{O}_{2}(0.5$ $\mathrm{mg} / \mathrm{ml}$ ) in $0.1 \mathrm{M}$ phosphate buffer, whole-mounted on a gelatin-coated glass slide, overlaid with a piece of filter paper, and dried for $2-3 \mathrm{hr}$. They were counterstained with $0.01 \%$ cresyl violet, dehydrated, and mounted in Entellan New (Merk). Comparison of the map made of HRP-injected cells in vitro (see below) with a similar map made for recovered cells in dehydrated retinas suggested that shrinkage in the plane of the retina was less than $3 \%$. The graft was dissected in order to confirm that the distance between the point of dye injection and the suture point was $10 \mathrm{~mm}$ or greater.

The somal contour of all the HRP-labeled cells was outlined with camera lucida at $600 \times$ magnification. Somal area was measured with the MACMEASURE program, and soma diameters equivalent to circles with the same area were calculated.
Dendritic field sizes of $H R P$-injected $R G C$. All the cells that exhibited clear dendritic arborization after intracellular injections of HRP (see below) were drawn on a white sheet at $600 \times$ magnification. In order to calculate dendritic field diameter, the largest diameter of the dendritic arborization was measured from the drawing. The diameter of the dendritic arborization orthogonal to this was measured and the dendritic diameter was calculated as the average of these two values.

\section{Intracellular injections}

In order to identify cells for intracellular injections, RGCs with regenerated axons were first retrogradely labeled with one fluorescent dye and subsequently injected with a second fluorescent dye that could be visualized with a different filter system. An epifluorescence microscope (Nikon Optiphot) was equipped with two filter systems, B-2A (excitation filter, $450-490 \mathrm{~nm}$; barrier filter, $520 \mathrm{~nm}$ long pass) and G-1 B (excitation filter, $535-550 \mathrm{~nm}$; barrier filter, $590 \mathrm{~nm}$ long pass). Cells to be intracellularly injected with Lucifer yellow $\mathrm{CH}$, which is seen with the B-2A filter, were retrogradely labeled with TMRD, which is visualized under the G-1B filter. Cells to be intracellularly injected with rhodamineconjugated HRP, which is seen with the G-1B filter, were retrogradely labeled with FLD, which is visualized under the B-2A filter.

Microelectrodes for intracellular injections. Glass capillaries (GC200F10, Clark) were pulled with a microelectrode puller (Narishige PE-2). For Lucifer yellow injection the microelectrodes were filled with 3\% (w/ v) Lucifer yellow CH (Sigma, L0259) in $50 \mathrm{~mm}$ Tris buffer, adjusted to pH 7.4 with $\mathrm{I}$ iOH. For HRP injection the microelectrodes were filled with a solution of rhodamine isothiocyanate-conjugated HRP (Sigma, P5031; $7.7 \mathrm{U} / \mu \mathrm{l})$ and Lucifer yellow $\mathrm{CH}(3.8 \mu \mathrm{g} / \mu \mathrm{l})$ in $50 \mathrm{~mm} 3-(\mathrm{N}$ morpholino)propanesulfonic acid (MOPS) buffer, adjusted to $\mathrm{pH} 7.0$ with $\mathrm{LiOH}$. Electrodes were beveled to a tip resistance of $60-100 \mathrm{M} \Omega$ with a K. T. Brown beveler (Sutter BV-10), and kept in a moisture box.

Intracellular injection of Lucifer yellow. Retinas of three cats were used. Under anesthesia, the operated eye was enucleated and hemisected at the equator with a razor blade. After enucleation the cats were killed by an overdose of sodium pentobarbital. The retina was dissected in Ames medium oxygenated with $95 \% \mathrm{O}_{2}, 5 \% \mathrm{CO}_{2}$ gas mixture, and affixed to a thin layer of $30 \%$ gelatin, ganglion cell side upward, in a chamber superfused with oxygenated Ames medium. TMRD-labeled cells were searched for under an epifluorescence microscope with a $40 \times$ water-immersion ohjective lens (7eiss 461703). The microelectrode was advanced into a TMRD-labeled cell with an oil-driven micromanipulator (Narishige MO-11), and then into all the labeled cells in the vicinity of the first cell in each restricted area until the electrode tip clogged. Negative-pulse currents, $8-15 \mathrm{nA}, 1 \mathrm{sec}$ on, $1 \mathrm{sec}$ off, were applied through the tip for 1-1.5 min. After the dendrites of a given cell were filled with Lucifer yellow, horizontal and vertical coordinates on the microscope stage and the morphological type of the cell were recorded. Lucifer yellow-filled cells were photographed at ISO $=3200$ (Fuji Super Presto) with the same objective lens. After the intracellular injections were completed, the retina was pealed off, fixed with $1 \%$ paraformaldehyde, and mounted in $0.1 \mathrm{M}$ phosphate buffer supplemented with $0.1 \%$ sodium azide.

Intracellular injection of HRP. The method has been described in detail elsewhere (Watanabe and Rodieck, 1989). Retinas of 11 cats were used for the intracellular injections of HRP. Retinas were dissected and affixed in a chamber as described above. The microelectrode containing rhodamine-conjugated HRP was advanced into FLD-labcled cclls under a $40 \times$ water-immersion lens in a fluorescence microscope. Rhodamine-HRP was ejected into labeled cells by applying positive-pulse current, 5-12 nA, $1 \mathrm{sec}$ on, $1 \mathrm{sec}$ off, for $1.5-2 \mathrm{~min}$. After confirmation of injection of rhodamine-HRP in the soma and primary dendrites, the horizontal and vertical coordinates of injected cells on a microscope stage were recorded to verify their positions after $\mathrm{DAB}$ reaction. The retina was then pealed off and fixed with $1 \%$ glutaraldehyde in $0.1 \mathrm{M}$ phosphate buffer, rinsed with $0.1 \mathrm{M}$ phosphate buffer, and reacted with $\mathrm{DAB}$ and $\mathrm{H}_{2} \mathrm{O}_{2}$. The retina was fixed onto a gelatin-coated slide, dried, dehydrated, and mounted in Entellan New.

\section{Results}

\section{Determination of the area centralis}

The density of RGCs is the highest, and their soma sizes are the smallest, within the area centralis of cat retinas (Wässle et al., 1975; Stone, 1978). However, in the retinas of the present 


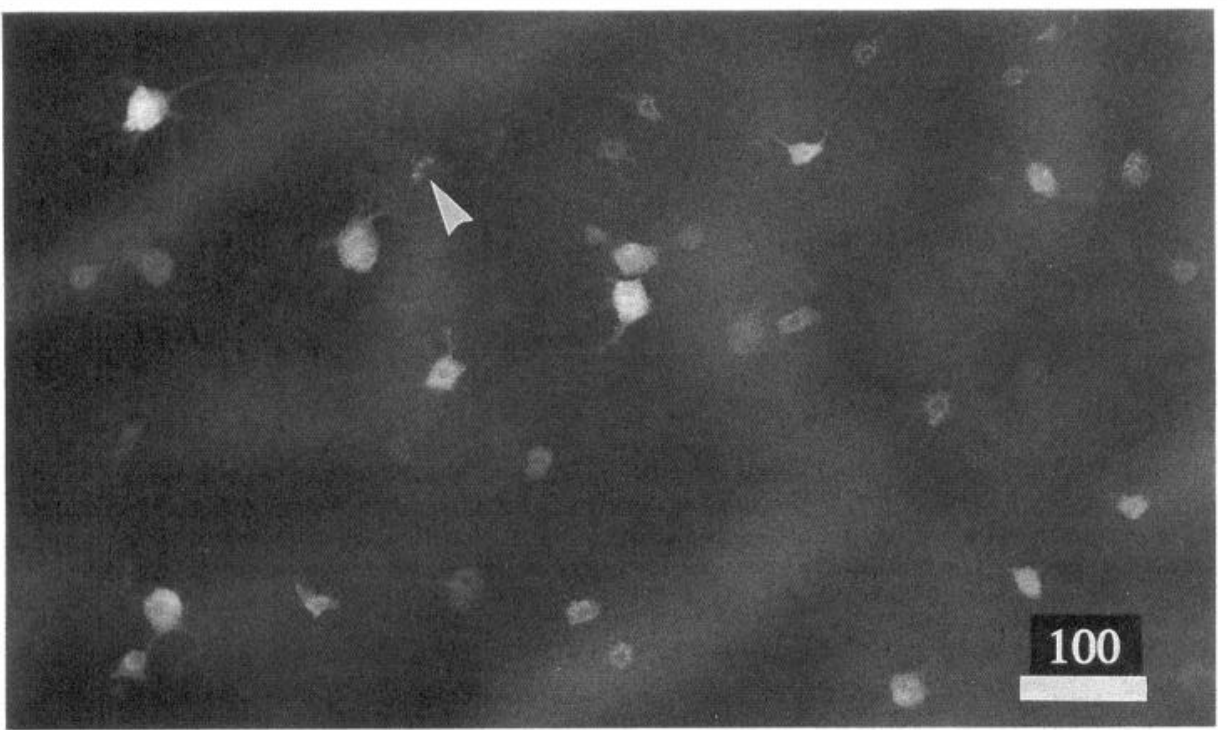

Figure 1. Photomicrograph of TMRDlabeled cells under 535-550 nm excitation filter and $590 \mathrm{~nm}$ long-pass barrier filter (Nikon G-1B filter). The fixed retina was mounted in phosphate buffer. Note that soma sizes of labeled cells vary and that primary dendrites of large cells and heavily labeled ones are visualized with the dye. All 36 cells in the figure (except for debris, arrowhead) were counted as labeled cells since their cytoplasm was filled with TMRD granules. Scale bar, $100 \mu \mathrm{m}$. study, a great majority of RGCs disappeared after axotomy and the soma size of RGCs with regenerated axons became larger (see below). For these reasons it was impractical to locate the area centralis by relying on cell density or soma size. We therefore used the blood vessel pattern to determine the location of the center of the area centralis (Bishop et al., 1962; Hughes, 1975; Wässle et al., 1975; Stone, 1978) and measured eccentricities of RGCs from this point. The presumptive centers of the area centralis were located $3.2-4.2 \mathrm{~mm}$ from the center of the optic disk. These distances were within the range of values reported in intact adult retinas (Bishop et al., 1962).

\section{Number and distribution of $R G C s$ regenerating their axons}

The numbers of RGCs that were identified as having regenerated their axons by retrogradely labeling with HRP ranged from 513 to 992 in our previous study (Watanabe et al., 1991a). These values correspond to $1 \%$ or less of the total number of RGCs in normal cat retinas. We found that more cells were labeled with TMRD injected concurrently into the graft but no TMRDlabeled cells could be detected after DAB reaction for HRP.

In the present study we labeled the RGCs with a dextranconjugated fluorescent dye (TMRD), which is more sensitive and less toxic. Only labeled cells that contained TMRD granules in the cytoplasm were counted regardless of the degree of labeling (Fig. 1). More than 4000 TMRD-labeled cells were found in the two retinas examined (Table 1). These numbers were 410 -fold greater than the numbers of HRP-labeled cells.

The distribution pattern of 4323 TMRD-labeled cells in wholemounted retina $55 \mathrm{~L}$ is shown in Figure 2. Labeled cells in five other retinas (HRP: 6L, 17L, 19L, 20L; TMRD: 52L) were distributed in similar patterns. Labeled cells were scattered over the retina but distributed most densely near the area centralis with a horizontal spread across the optic disk towards the nasal retina. Except for a relative sparse distribution of labeled cells in the areas dorsal and ventral to the optic disk, the distribution of regenerating cells resembles the distribution of RGCs in intact cat retinas (Fig. 7A of Hughes, 1975; Fig. 5 of Stone, 1978).

\section{Soma size of $R G C s$ with regenerated axons}

The soma sizes of all the regenerating RGCs $(N=1769)$ that were retrogradely labeled with HRP were measured in three retinas $(6 \mathrm{~L}, 17 \mathrm{~L}$, and $19 \mathrm{~L})$. Soma diameter ranged from $8.8 \mu \mathrm{m}$ to $51.6 \mu \mathrm{m}$, with mean diameter of $29.0 \mu \mathrm{m} \pm 6.6( \pm \mathrm{SD})$. Twenty-one percent of the labeled cells had soma diameters larger than $35 \mu \mathrm{m}$, which is the upper limit of RGC diameters in intact cat retinas (Hughes, 1981). These larger cells were randomly distributed even within the central retina, and there was no tendency for their density to increase in the periphery.

Figure 3 shows soma size spectra of HRP-labeled cells found at eccentricities of more than $3 \mathrm{~mm}$ in three retinas $(6 \mathrm{~L}, 17 \mathrm{~L}$, and 19L). The ranges of soma diameter of $\gamma-, \beta$-, and $\alpha$-cells obtained from Nissl-staining in the periphery of intact retinas are shown for comparison (Fig. 5 of Hughes, 1981). The range of soma diameters was shifted to the right in RGCs with regenerated axons. In peripheral regions of the intact cat retina, the distribution histogram of RGCs is trimodal, with $\gamma, \beta$, and $\alpha$ peaks (Hughes, 1981). In contrast, the distribution of RGCs with regenerated axons was unimodal with a broad peak from 20 to $36 \mu \mathrm{m}$.

The shift to the right of the size distribution could reflect an enlargement of all RGCs that regenerated their axons. It is also possible that axonal regeneration did not occur in smaller cells and that soma size increased in $\alpha$ - and $\beta$-cells with regenerated axons.

\section{Morphological types of RGCs regenerating their axons}

A total of 189 cells labeled retrogradely with FLD were penetrated with HRP-filled electrodes, but only 45 cells were filled well enough to be examined in detail. These RGCs were classified on the basis of their dendritic morphology. Although several other morphological types have been reported in the cat

Table 1. Number of RGCs with regenerated axons counted as cells labeled with TMRD

\begin{tabular}{lll}
$\begin{array}{l}\text { Experiment } \\
\text { number }\end{array}$ & $\begin{array}{l}\text { Survival time } \\
\text { (d) }\end{array}$ & $\begin{array}{l}\text { Total number } \\
\text { of labeled cells }\end{array}$ \\
\hline 52 & 64 & 5040 \\
$55^{a}$ & 65 & 4323 \\
\hline
\end{tabular}

${ }^{a}$ The whole-mounted retina and distribution of labeled cells are depicted in Figure 2 . 
Figure 2. The distribution of RGCs regenerating their axons in a flatmounted retina $(55 \mathrm{~L})$. Each dot represents a single cell. RGCs regenerating their axons were labeled retrogradely with TMRD, as shown in Figure 1. The area centralis $(A C)$ is located at the projected intersection of the two arrows. $O D$, optic disk.

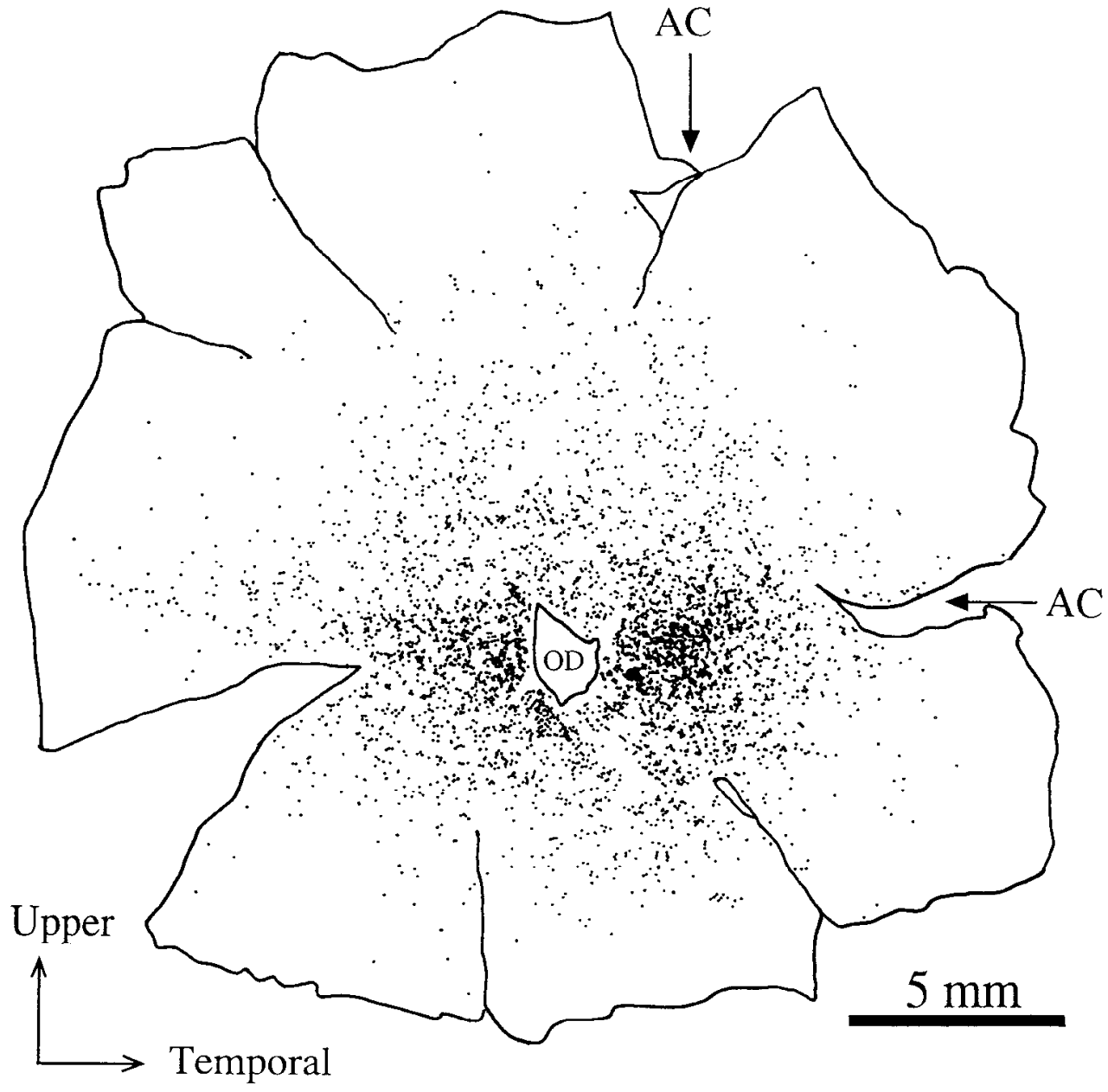

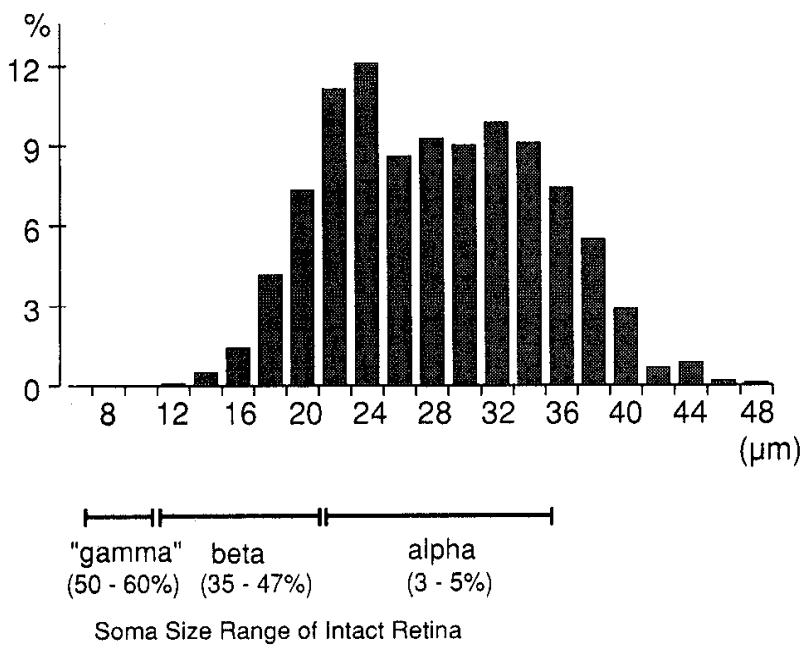

Figure 3. Soma size spectra of RGCs $(N=1223)$ with regenerated axons situated at $3 \mathrm{~mm}$ eccentricity or greater in three retinas $(6 \mathrm{~L}, 17 \mathrm{~L}$, 19L). Bars at the bottom express range of soma diameters of RGCs at far periphery of the intact retina, from Figure 5 of Hughes (1981). Numbers in parentheses are population ratios of the modes. The "gam$m a$ " in the range does not mean $\gamma$-typc only, but includes all the small cells that are not $\alpha$ or $\beta$. retina (Brening and Rodieck, 1986; Rodieck and Watanabe, 1986), we classified these RGCs into $\alpha$-, $\beta$-, and $\gamma$-types (Boycott and Wässle, 1974; Wässle et al., 1981; Saito, 1983; Fukuda et al., 1984; Stanford and Sherman, 1984; Peichl et al., 1987), and a remaining category.

$\alpha$-Cells. $\alpha$-Cells in intact retinas have four to six thick primary dendrites with many branches that cover a wide dendritic field. The shape of the dendritic field is roughly round or oval, and the soma is situated in the center of the dendritic field. Twentythree cells exhibited typical $\alpha$-cell morphology described above. Three representative examples are illustrated in Figure 4.

$\beta$-Cells. $\beta$-Cells in the intact cat retina have extensive bushy branching within a smaller field than in other types. Eleven cells were categorized as $\beta$-cells on the basis of the morphological criteria, and three of them are illustrated in Figure 5. Seven cells had the similar dendritic morphology, and one of them is shown in Figure $5 B$. Two $\beta$-cells appeared to have lost several primary dendrites, and the soma was situated eccentrically with respect to the dendritic field (Fig. $5 A$ ). Two $\beta$-cells had thin, short dendrites emanating directly from the soma, and had a long, thick process that extended into the optic nerve layer (Fig. 5C). This process, which was morphologically different from the axon and dendrites, may have regrown during axonal regeneration. These processes were also observed in some unclassified cells injected 


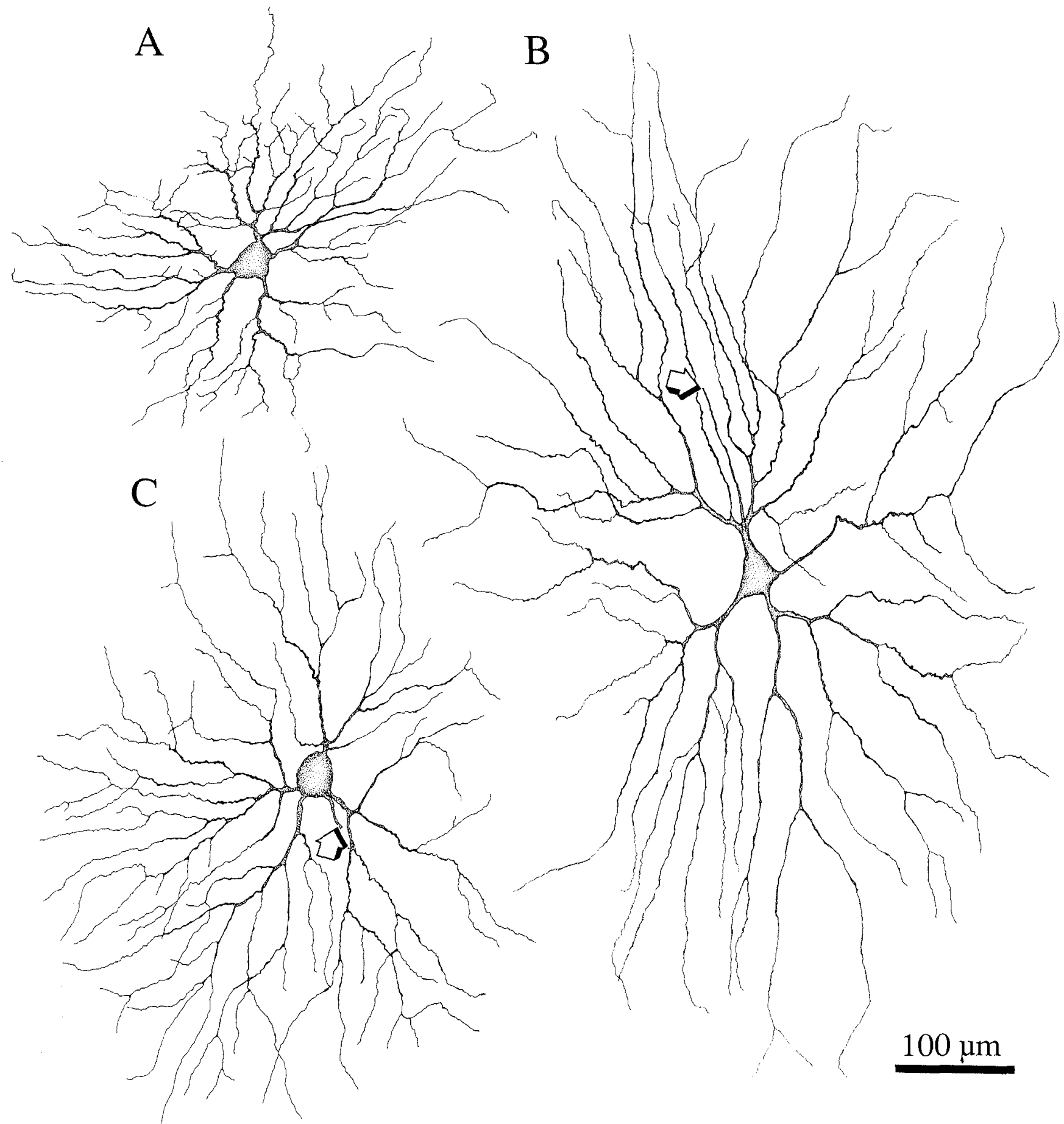

Figure 4. Illustration of $\alpha$-cells visualized with the HRP intracellular injection method. All the cells were situated in the upper retina. $A$, eccentricity $=1.9 \mathrm{~mm} ; B$, eccentricity $=4.6 \mathrm{~mm} ; C$, eccentricity $=2.6 \mathrm{~mm}$. The axons are indicated with open arrows, except in $A$, where the axon was over a primary dendrite and was not drawn. Dendrites in all the cells spread widely and ramified frequently. The soma of each cell is situated in the center of the dendritic field.

with Lucifer yellow, and resembled processes in rat RGCs with regenerated axons (Tabata and Fukuda, 1992).

$\gamma$-Cells. Features identifying $\gamma$-cells are two to four slender primary dendrites that spread extremely widely and ramify less frequently than those of other types (Boycott and Wässle, 1974; Stone and Clarke, 1980; Fukuda et al., 1984; Rodieck and Watanabe, 1986). Dendritic field size of $\gamma$-cells is fairly constant at any eccentricity from the area centralis. Three cells obtained from HRP injections had very long, slender dendrites. Two of these are illustrated in Figure 6. The cell illustrated in Figure $6 B$ appears as a typical $\gamma$-cell but the distal dendrites of the cell shown in Figure $6 A$ and another cell that is not illustrated had fine processes, some of which are indicated with small arrows in the figure. Although these processes have not been reported 


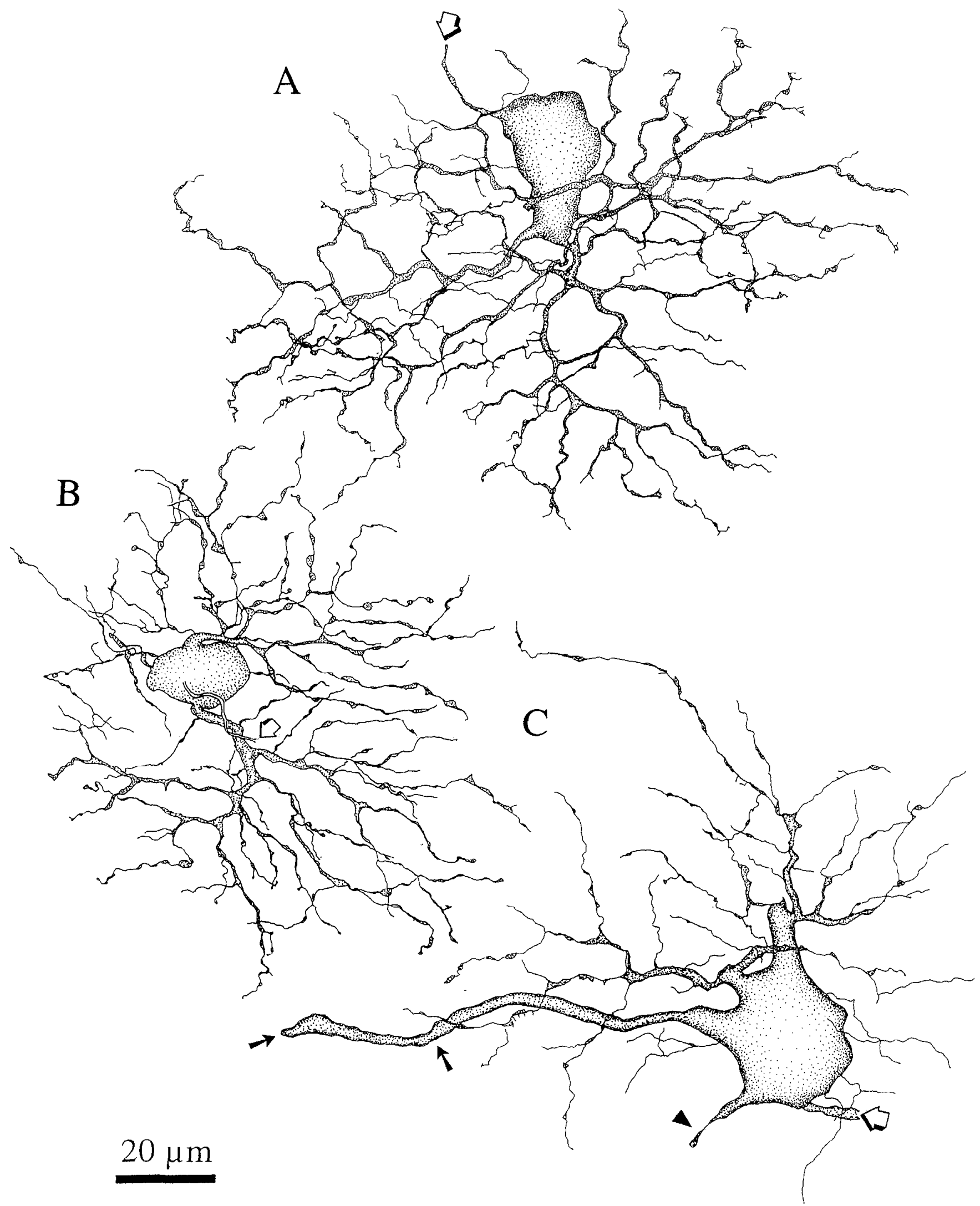

Figure 5. Illustration of $\beta$-cells visualized with the HRP intracellular injection method. Open arrows, axon. $A$, Cell from the upper nasal retina $($ eccentricity $=2.6 \mathrm{~mm}$ ) with its soma eccentric to the dendritic field. $B$, From the upper temporal retina; eccentricity $=3.4 \mathrm{~mm}$. $C$, From the nasal retina; eccentricity $=7.7 \mathrm{~mm}$. The dendrites of the cell in $C$ were very short and thin, and one primary dendrite showed degenerative change (arrowhead). This cell had a process that grew in the optic nerve layer after transplantation (solid arrows). 


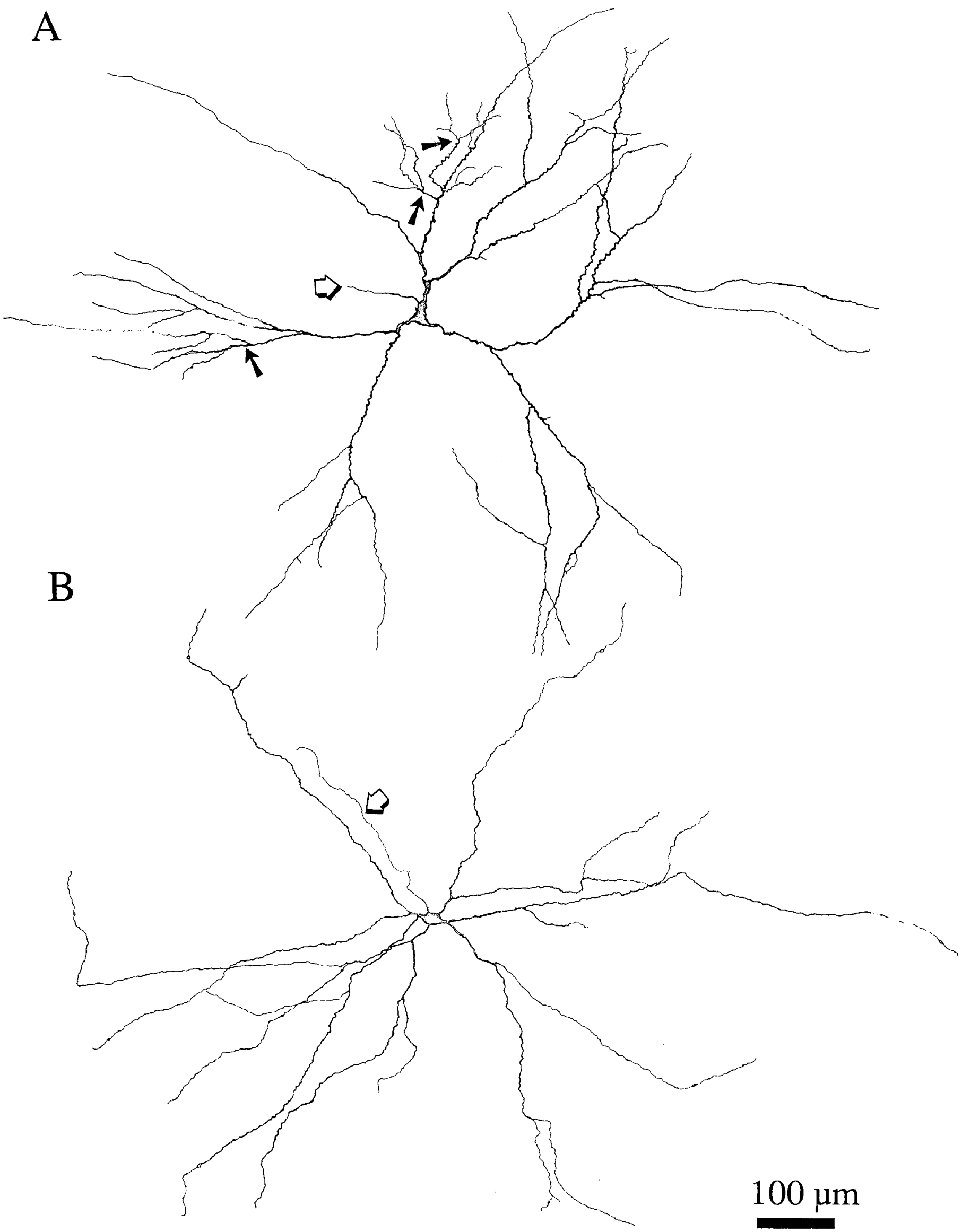

Figure 6. Illustration of two $\gamma$-cells visualized with the HRP intracellular injection method. Open arrows, axon. $A$, From the lower nasal retina; eccentricity $=5.6 \mathrm{~mm}$. $B$, From the upper temporal retina; eccentricity $=2.3 \mathrm{~mm}$. Straight dendrites of both cells spread widely, up to $570 \mu \mathrm{m}$ $(A)$ or $660 \mu \mathrm{m}(B)$. Note many fine processes at distal dendrites of the cell in $A$, some of which are indicated with solid arrows. 


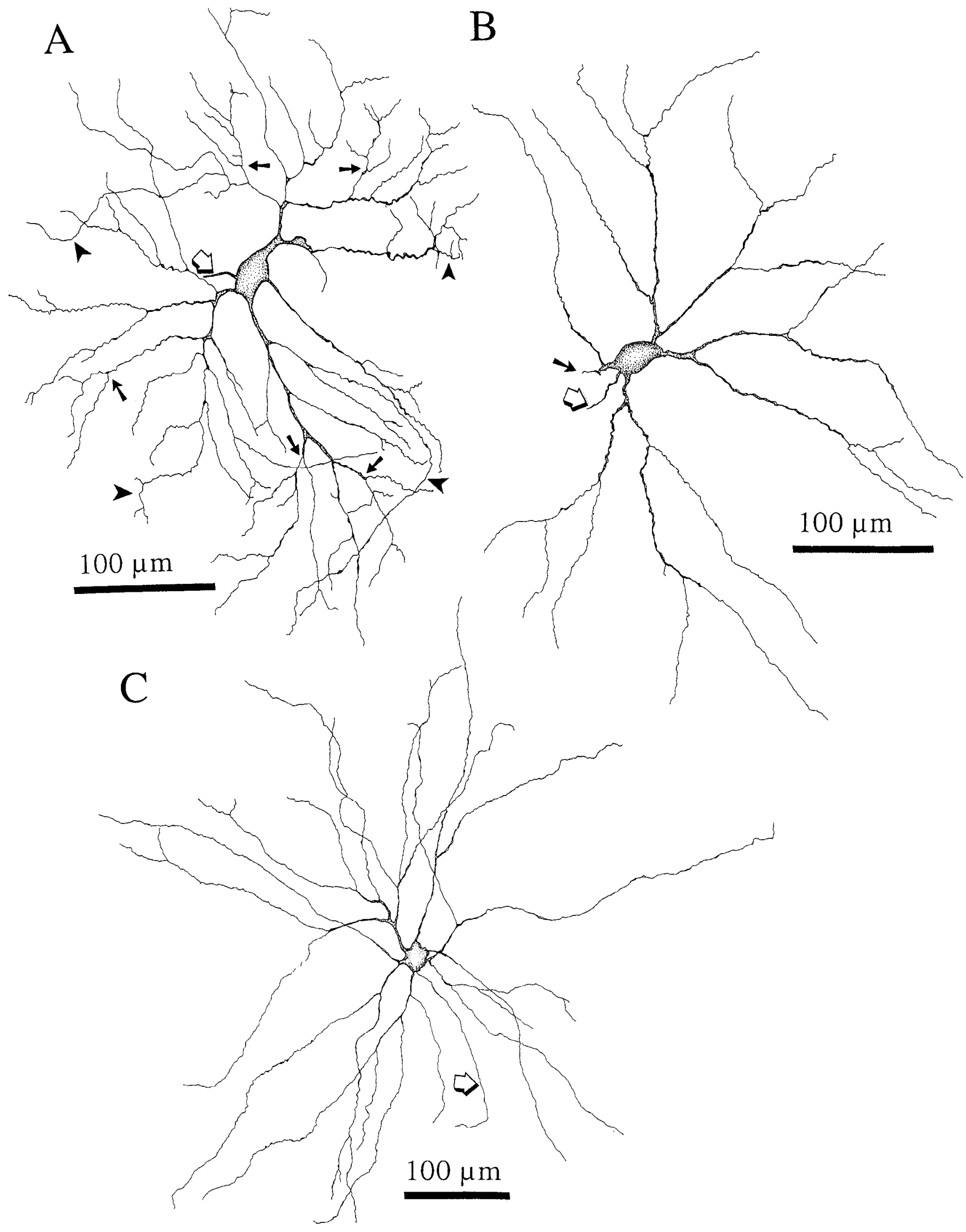




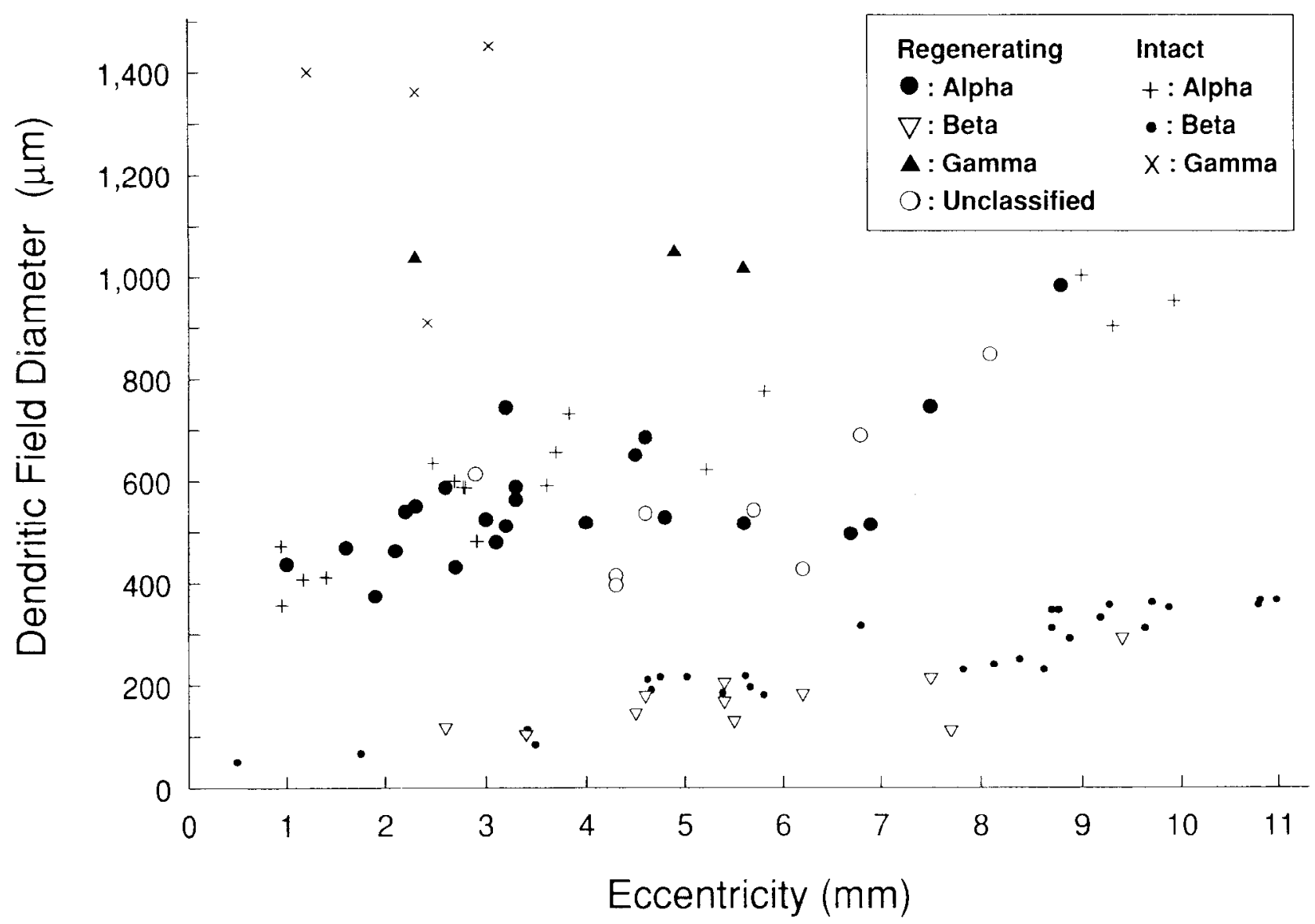

Figure 8. Scatter diagram of dendritic field size of RGCs obtained from the HRP intracellular injection as $\alpha$-cells $(N=23), \beta$-cells $(N=11)$, $\gamma$-cells $(N=3)$, and unclassified cells $(N=8)$. For comparison, data from intact retinas are also plotted $(\alpha$-cells, $N=17 ; \beta$-cells, $N=29 ; \gamma$-cells, $N=4$ ). Data for intact retinas were obtained from RGCs projecting to the cat lateral geniculate nucleus (Rodieck and Watanabe, 1986).

in $\gamma$-cells in intact retinas, these two cells were categorized as $\gamma$-cells on the basis of the configuration of their primary dendrites.

Unclassified cells. Eight cells that could not be classified as $\alpha-, \beta$-, or $\gamma$-cells were categorized as "unclassified." A common feature of unclassified cells was having very thin dendrites and a smaller dendritic field than that of $\gamma$-cells, although there was no general pattern of dendritic arborization. Typical examples of such cells are illustrated in Figure 7 . The cell in Figure $7 A$ resembled an $\alpha$-cell but had many short processes on the distal dendrites (arrows), some of which were curly (arrowheads). These processes were extremely thin and seemed to grow during axonal regeneration (Tabata and Fukuda, 1992). Dendritic arborization of the cell in Figure $7 B$ was the least of all the successfully injected cells, and one of the primary dendrites of this cell appeared to be unbranched (solid arrow). The primary dendrites of the cell in Figure $7 C$ were thin and ramified near the soma. Its distal dendrites were long and gave rise to very few branches.

\section{Dendritic field diameter as a function of eccentricity}

The diameters of dendritic fields of the 45 cells studied in detail were plotted in scatter diagrams against eccentricity (Fig. 8). Values obtained with the same injection method in intact retinas are shown for comparison (Rodieck and Watanabe, 1986). $\alpha$-Cells $(N=23), \beta$-cells $(N=11)$, and $\gamma$-cells $(N-3)$ with regenerated axons clustered separately within ranges corresponding to the clusters of intact $\alpha$-cells $(N=17), \beta$-cells $(N=29)$, and $\gamma$-cells $(N=4)$ that projected to the cat lateral geniculate nucleus. Dendritic field sizes of $\alpha$ - and $\beta$-cells increased with their eccentricity, whereas the wide dendritic field sizes of three $\gamma$-cells were constant. The points corresponding to some of the unclassified cells $(N=8)$ were found within the region characteristic of $\alpha$-cells. This suggests that these unclassified cells may have originally been $\alpha$-cells, but that their dendritic processes degenerated and/or grew during axonal regeneration, leading to their categorization as unclassified.

Figure 7. Illustration of three typical examples of unclassified cells obtained from the HRP intracellular injection method. Open arrows, axon. A, From the upper retina; eccentricity $=4.3 \mathrm{~mm}$. Distal dendrites of this cell have many fine processes (solid arrows), some of which curved (arrowheads). $B$, From the upper retina; eccentricity $=6.2 \mathrm{~mm}$. The dendrites have fewer processes than the cells in $A$ and $C$, and one branch of a primary dendrite showed only a short stump (solid arrow), which suggests degeneration of the dendrite. $C$, From the upper retina; eccentricity $=2.9$ mm. The fine primary dendrites are short and distal dendrites are long with few ramification. Morphology of cell in $C$ was similar to that of the cell in Figure $9 D$. 

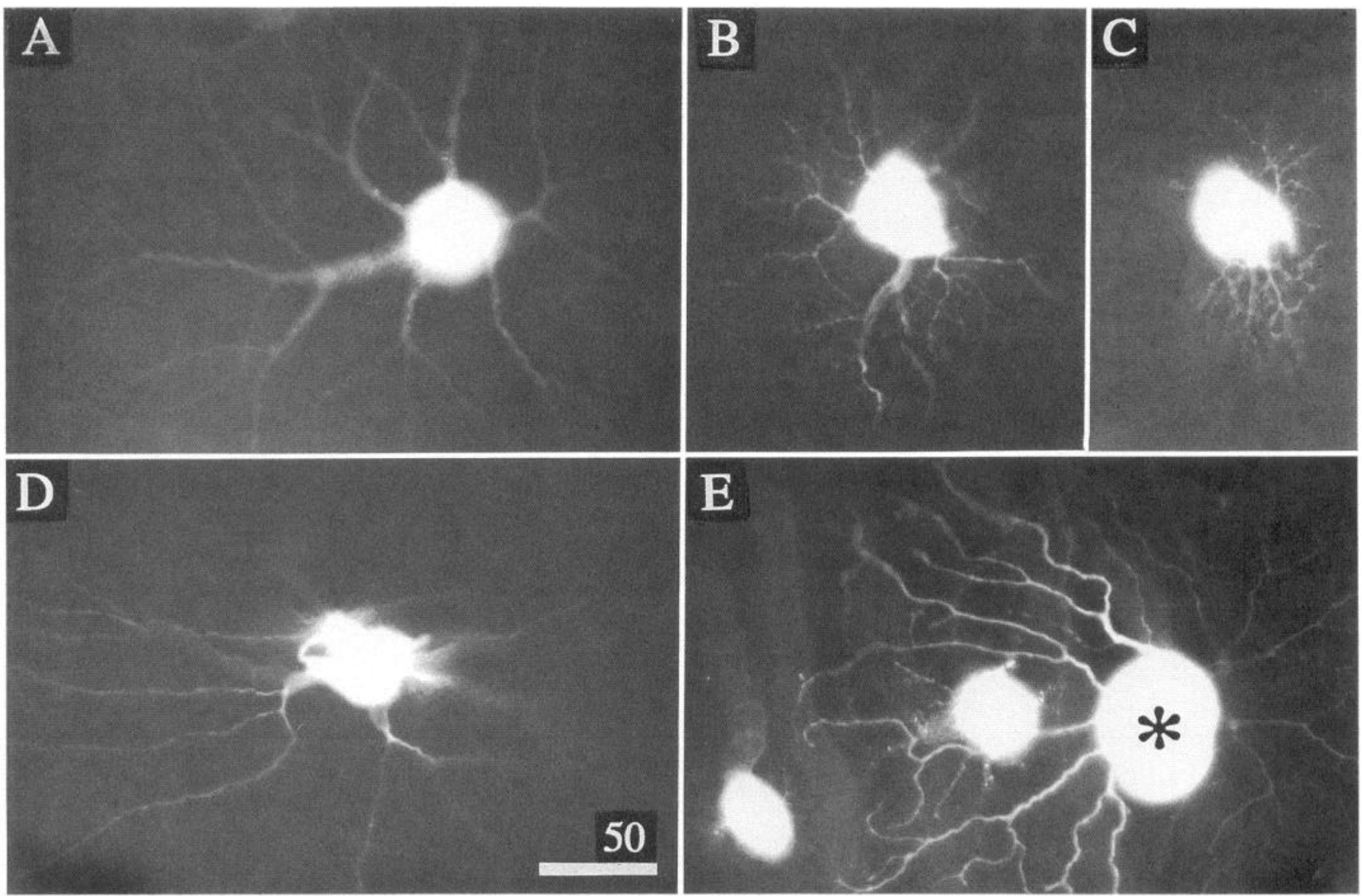

Figure 9. Photomicrographs of $\alpha$-cells $(A), \beta$-cells $(B, C)$, and NAB cells $(D, E)$ obtained from the Lucifer yellow injection. Dendritic morphology was photographed during injection in unfixed retina 52L with a water-immersion $40 \times$ lens at $450-490 \mathrm{~nm}$ excitation filter, $520 \mathrm{~nm}$ long-pass barrier filter (Nikon B-2A filter). $A$, Eccentricity $=5.6 \mathrm{~mm}$ in the upper nasal retina. $B$, Eccentricity $=5.2 \mathrm{~mm}$ in the upper nasal retina. $C$, Eccentricity $=3.3 \mathrm{~mm}$ in the lower nasal retina. $D$, Eccentricity $=13.2 \mathrm{~mm}$ in the nasal retina. $E$, Eccentricity $=2.7 \mathrm{~mm}$ in the lower nasal retina. Dendrites of the cell at the right (asterisk) in $E$ were slender in the right half of dendritic field. Scale bar, $50 \mu \mathrm{m}$.

\section{Proportion of $\alpha$ - and $\beta$-cells in regenerating population}

There are limitations in the use of the HRP intracellular injection method to identify the proportion of the various cell types that regenerate their axons. HRP is injected into only a small number of selected cells, and not all the injected cells are visualized after DAB reaction ( $24 \%$ success in the present study). A more accurate estimate of the proportions of cell types that regenerated their axons was obtained by the injection of Lucifer yellow (Tauchi and Masland, 1984) into as many cells as possible within a given retinal area. Each injected group comprised about $20-80$ cells situated in the superior, nasal, temporal, or inferior retina or near the area centralis.

$\alpha$ - and $\beta$-cells were easily identified following Lucifer yellow injection (Fig. 9A-C), but it was difficult to follow the full length of thin dendrites, such as those of $\gamma$-cells (Fig. 6). Because of this limitation, cells that were not $\alpha$ nor $\beta$ were categorized as "not $\alpha$ - or $\beta$-" (NAB). The NAB cell group, which contains many morphological types, should correspond to the " $\gamma$-mode" in Hughes (1981). Figure 9, $D$ and $E$, shows some examples of NAB cells. As observed for unclassified cells, the dendrites of the cell in Figure $9 D$ were long and thin, and ramified less frequently than those of $\alpha$-cells. The cell in Figure $9 E$, which resembled an $\alpha$-cell, had curly dendrites that became slender in the right half of the field. This observation suggests degenerative changes of the dendrites.

The relative proportions of the three categories of cells were determined in several patches for three retinas. One example is shown in whole-mounted retina $55 \mathrm{~L}$ (Fig. 10). In the four patches located in the area centralis, upper, upper nasal, and lower nasal retinas, all three types of cells were found, with $\beta$-cells constituting the largest proportion of the cells (Fig. 10B). Similar results were found in every patch of the other retinas $(51 \mathrm{~L}, 52 \mathrm{~L})$ examined.

Table 2 summarizes the proportion of $\alpha-, \beta$-, and NAB cells regenerating their axons in three retinas. Although $\beta$-cells comprised the largest group of RGCs with regenerated axons, the proportion of $\alpha$-cells regenerating their axons increased four- to sevenfold in comparison to the proportion of $\alpha$-cells in intact retinas. In contrast, the proportion of NAB cells regenerating their axons decreased to approximately half or less of that found in intact retinas. The proportion of $\beta$-cells regenerating their axons was unchanged or slightly increased.

\section{Discussion}

Number and distribution of RGCs regenerating their axons In the previous study, RGCs regenerating their axons were counted on cells labeled retrogradely with HRP, and their num- 

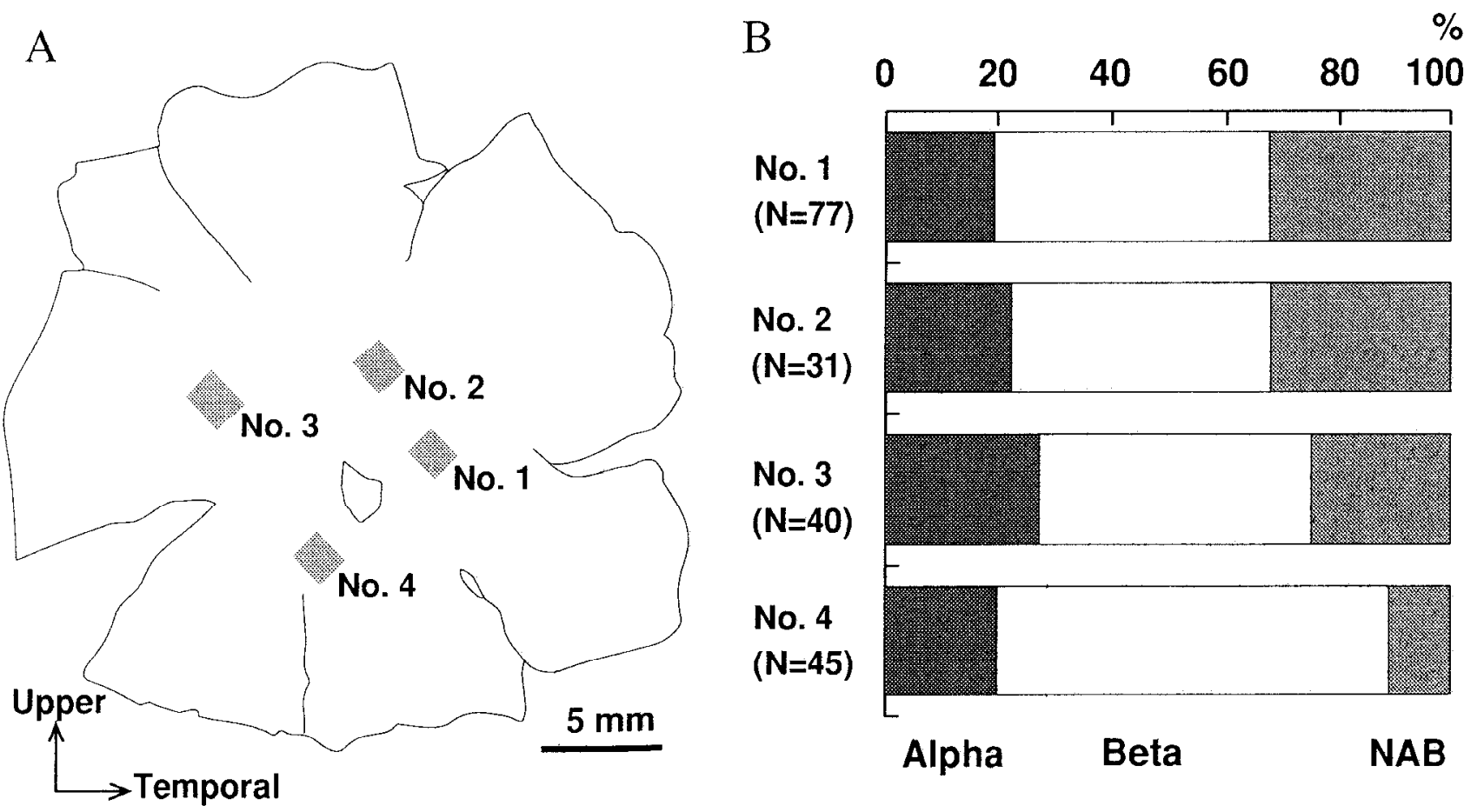

Figure 10. An example of injection maps, retina 55L. A, Location of four patches where Lucifer yellow was injected into cells in the wholemounted retina. They were located in the area centralis ( $N o .1)$, upper retina (No. 2), upper nasal (No. 3), and lower nasal (No. 4). $B$, Proportions of $\alpha$-cells (dark shading), $\beta$-cells (no shading), and NAB cells (light shading) cells in the four patches.

bers varied from 513 to 992 (Watanabe et al., 1991a). More than 4000 TMRD-labeled cells were found in the present study. Nonetheless, this was still only $3.0-4.3 \%$ of total ganglion cell number in the intact retina (Stone, 1978; Hughes, 1981; Chalupa et al., 1984), and 2.6-3.9\% of fiber counts in the normal optic nerve (Hughes and Wässle, 1976; Stone and Campion, 1978; Chalupa et al., 1984).

We previously reported that regenerating ganglion cells were distributed most densely near the optic disk (Fukuda et al., 1991; Watanabe et al., 1991a). However, when more regenerating cells were labeled and plotted in the whole-mounted retina, the distribution resembled that of intact retinas. It is therefore possible that there is small difference in capacity of axonal regeneration among cells different distances from the optic disk.

\section{Enlargement of soma size of regenerating $R G C s$ ?}

The soma size distribution of regenerating $\mathrm{RGCs}$ was shifted to the right in comparison to RGC soma size distribution in the intact cat retina and was broader and unimodal rather than trimodal as is found in peripheral regions of the intact retina. This finding could imply enlargement of all types of RGCs regenerating their axons. However, the loss of the peaks corresponding to $\alpha$-, $\beta$-, and smaller cells (" $\gamma$-mode" in Hughes, 1981) and the absence of regenerating RGCs with soma diameters in the normal smaller cell range are also consistent with the possibility that there was preferential loss of smaller cells following axotomy and that there was preferential regenerating of axons from larger-diameter RGCs ( $\alpha$ and $\beta$ ). Thanos (1988) also noted

Table 2. Proportion of $\alpha$ - and $\beta$-ganglion cells that regenerated the axon

\begin{tabular}{|c|c|c|c|c|}
\hline & \multirow{2}{*}{$\begin{array}{l}\text { Total } \\
\text { number } \\
\text { of cells } \\
\text { injected }\end{array}$} & \multicolumn{3}{|c|}{ Proportion of cell types } \\
\hline & & $\alpha$ & $\beta$ & $\mathrm{NAB}^{a}$ \\
\hline \multicolumn{5}{|l|}{ Retinas with nerve graft } \\
\hline $51 \mathrm{~L}$ & 112 & $18.8 \%$ & $61.6 \%$ & $19.6 \%$ \\
\hline $52 \mathrm{~L}$ & 138 & $31.2 \%$ & $38.4 \%$ & $30.4 \%$ \\
\hline $55 \mathrm{~L}$ & 193 & $21.8 \%$ & $52.3 \%$ & $25.9 \%$ \\
\hline Average & & $23.9 \%$ & $50.3 \%$ & $25.7 \%$ \\
\hline Intact retinas ${ }^{b}$ & & $4.2 \%$ & $40.4 \%$ & $55.6 \%$ \\
\hline $\begin{array}{l}\text { Relative proportions of cells: } \\
\text { (retinas with nerve graft)/(intact retinas) }\end{array}$ & & 5.7 & 1.2 & 0.46 \\
\hline
\end{tabular}

a NAB, not $\alpha$ or $\beta$ (examples are shown in Fig. 9D, E).

${ }^{b}$ Average of the values in Figure 5 of Hughes (1981). The values in the area centralis and near the visual streak, however, did not show trimodal segregation as in other five peripheral areas, so they were excluded from calculation. 
an apparent preferential loss of smaller-diameter RGCs following axotomy in the rat.

\section{Classification of $R G C s$ with regenerated axons}

The dendritic morphology of $\alpha$-cells with regenerated axons was distinguishable from that of other cell types after injections of HRP or Lucifer yellow. The dendritic field sizes of the $\alpha$-cells did not change greatly after axotomy and axonal regeneration (Fig. 8). Some cells that were classified as $\beta$-cells showed dendritic morphology atypical of that of $\beta$-cells in intact retinas (Fig. $5 C$ ). However, when their dendritic field size was plotted against eccentricity, these cells remained within the range of $\beta$-cells of intact retinas. Dendritic field sizes of the three $\gamma$-cells were also similar to those of the normal $\gamma$-cells. These results suggest that the morphological types of the RGCs classified as $\alpha, \beta$, and $\gamma$ were the same before and after axonal regeneration. Any cells that could not be recognized as one of these three types were categorized as "unclassified." 'This categorization does not imply a new morphological type, but may include cells that could have been one of the known cell types.

\section{Original type(s) of unclassified cells}

More than half (50-60\%) of RGCs in intact cats are classified as NAB (not $\alpha$ or $\beta$; Rodieck, 1979). This category includes $\gamma$-cells, other reported morphological types, and possibly unknown type(s). Among the other types of cells that have been identified in HRP-injected RGCs in cats are ivy cells, which project to the superior colliculus (Brening and Rodieck, 1986), $\kappa$ - and $\lambda$-cells, which project to the geniculate nucleus, and $\epsilon$-cells, which project to the geniculate wing (Rodieck and Watanabe, 1986). Most of the unclassified cells in the present study, however, do not correspond to any of these types (Fig. 7). One possible explanation is that our unclassified cells belonged originally to one of the known cell types but changed morphologically after their dendrites degenerated and/or grew.

Somc of HRP-fillcd unclassified cells were situated within the range characteristic of $\alpha$-cells when their dendritic field size was plotted against eccentricity. This finding suggests that at least some unclassified cells may have been $\alpha$-cells before dendritic degeneration and/or growth. Examples of such cells are illustrated in Figures $7 A$ and $9 E$.

\section{Increased representation of $\alpha$-cells in the regenerating $R G C$. population}

Hughes (1981) reported that in the retina of adult cats $\alpha-, \beta$-, and other cell types constitute $3-5 \%, 35-47 \%$, and $50 \%$, respectively. Although his estimate was based on soma size measurement from Nissl-stained retinas, it is consistent with other reports that used the reduced silver staining method (Wässle et al., 1981), physiological recordings (Fukuda and Stone, 1974), or electron microscopy of axons of RGCs (Williams and Chalupa, 1983; Hsiao et al., 1984). The present study with Lucifer yellow injection permitted more precise categorization of morphological types of RGCs with regenerated axons, and made it possible to compare the proportions of different types of RGCs with those in normal retinas. In the retinas examined, the proportion of $\alpha$-cells was $18-31 \%$, which was as much as sevenfold greater than found in intact cat retinas. The proportion of $\beta$-cells was almost unchanged, but the proportion of NAB (i.c., the " $\gamma$-mode" of Hughes, 1981) was reduced to half or less.

We do not have direct evidence for original morphological type(s) of RGCs that were unclassified after axonal transection and regeneration. If, as suggested above, some of the unclassified cells were originally $\alpha$-cells, the proportion of $\alpha$-cells among RGCs with regenerated axons will be even greater than 18-31\%.

In conclusion, $\alpha$-cells were shown to have the greatest capacity to regenerate their axons into a peripheral nerve graft. It would be interesting to know whether the apparent greater ability of $\alpha$-cells to regenerate their axons reflects substantial difference from other types of RGCs in biological properties such as neurofibrillar contents (Wässle et al., 1981; Peichl et al., 1987).

\section{References}

Bishop PO, Kozak W, Vakkur GJ (1962) Some quantitative aspects of the cat's eye: axis and plane of reference, visual field co-ordinates and optics. J Physiol (Lond) 163:466-502.

Boycott BB, Wässle H (1974) The morphological types of ganglion cells of the domestic cat's retina. J Physiol (Lond) 240:397-419.

Brening RK, Rodieck RW (1986) Morphology of cat ganglion cells that project to the superior colliculus. Invest Ophthalmol Vis Sci 27: 223.

Carter DA, Bray GM, Aguayo AJ (1989) Regenerated retinal ganglion cell axons can form well-differentiated synapses in the superior colliculus of adult hamsters. J Neurosci 9:4042-4060.

Chalupa LM, Williams RW, Henderson Z (1984) Binocular interaction in the fetal cat regulates the size of the ganglion cell population. Neuroscience 12:1139-1146.

Cleland BG, Levick WR (1974) Brisk and sluggish concentrically organized ganglion cells in the cat retina. J Physiol (Lond) 240:421456.

Fukuda Y, Stone J (1974) Retinal distribution and central projections of Y-, X- and W-cells of the cat's retina. J Neurophysiol 39:749-772.

Fukuda Y, Hsiao C-F, Watanabe M, Ito H (1984) Morphological correlates of physiologically identified $\mathrm{Y}_{-}, \mathrm{X}-$, and $\mathrm{W}$-cells in the cat retina. J Neurophysiol 52:999-1013.

Fukuda Y, Watanabe M, Sawai H (1991) Axonal regeneration of cat retinal ganglion cells after peripheral nerve transplant. Invest Ophthalmol Vis Sci 32:1133.

Hsiao CF, Watanabe M, Fukuda Y (1984) The relation between axon diameter and axonal conduction velocity of $Y, X$ and $W$ cells in the cat retina. Brain Res 309:357-361.

Hughes A (1975) A quantitative analysis of the cat retinal ganglion cell topography. J Comp Neurol 163:107-128.

Hughes A (1981) Population magnitude and distribution of the major modal classes of cat retinal ganglion cell as estimated from HRP filling and a systematic survey of the soma diameter spectra for classical neurons. J Comp Neurol 197:303-339.

Hughes A, Wässle H (1976) The cat optic nerve: fibre total count and diameter spectrum. J Comp Neurol 169:171-184.

Peichl L, Ott H, Boycott BB (1987) Alpha ganglion cells in mammalian retinae. Proc R Soc Lond [Biol] 231:169-197.

Rodieck RW (1979) Visual pathways. Annu Rev Neurosci 2:193-225.

Rodieck RW, Watanabe M (1986) Morphologic diversity in the ganglion cell projection to different zones within the cat lateral geniculate nucleus. Soc Neurosci Abstr 12:1038.

Saito H (1983) Morphology of physiologically identified X-, Y-, and W-type retinal ganglion cells of the cat. I Comp Neurol 221:279-288.

So KF, Aguayo AJ (1985) Lengthy regrowth of cut axons from ganglion cells after peripheral nerve transplantation into the retina of adult rats. Brain Res 328:349-354.

Stanford LR, Sherman SM (1984) Structure/function relationships of retinal ganglion cells in the cat. Brain Res 297:381-386.

Stone J (1978) The number and division of ganglion cells in the cat's retina. J Comp Neurol 180:753-772.

Stone J, Campion JE (1978) Estimate on the number of myelinated axons in the cat's optic nerve. J Comp Neurol 180:799-806.

Stone J, Clarke R (1980) Correlation between soma size and dendritic morphology in cat retinal ganglion cells: evidence of further variation in the $\gamma$-cell class. J Comp Neurol 192:211-217.

Stone J, Fukuda Y (1974) Properties of cat retinal ganglion cells: a comparison of W-cells with X-and Y-cells. J Neurophysiol 37:722748.

Tabata T, Fukuda Y (1992) Dendritic regrowth of retinal ganglion cells in adult rats. Neuroreport 8:709-712.

Tauchi M, Masland RH (1984) The shape and arrangement of cho- 
linergic neurons in the rabbit retina. Proc R Soc Lond [Biol] 223: 101-119.

Thanos S (1988) Alterations in the morphology of ganglion cell dendrites in the adult rat retina after optic nerve transection and grafting of peripheral nerve segments. Cell Tissue Res 254:599-609.

Vidal-Sanz M, Bray GM, Villegas-Pérez MP, Thanos S, Aguayo AJ (1987) Axonal regeneration and synaptic formation in the superior colliculus by retinal ganglion cells in the adult rat. J Neurosci 7:28942909.

Wässle H, Levick WR, Cleland BG (1975) The distribution of the alpha type of ganglion cells in the cat's retina. J Comp Neurol 159: 419-438.

Wässle II, Peichl L, Boycott BB (1981) Morphology and topography of on- and off-alpha cells in the cat retina. Proc R Soc Lond [Biol] 212:157-175.

Watanabe M, Rodieck RW (1989) Parasol and midget ganglion cells of the primate retina. J Comp Neurol 289:434-454.

Watanabe M, Sawai H, Fukuda Y (1991a) Axonal regeneration of retinal ganglion cells in the cat geniculocortical pathway. Brain Res 560:330-333.

Watanabe M, Sawai H, Fukuda Y (1991b) Dendritic morphology and stratification of ganglion cells that regenerated axons in the cat retina. In: Third IBRO World Congress of Neuroscience, p. 33.

Williams RW, Chalupa LM (1983) An analysis of axon caliber within the optic nerve of the cat: evidence of size groupings and regional organization. J Ncurosci 3:1554-1564. 